\author{
Roman SLAVÍK $^{1^{*}}$, Markéta JULINOVÁ ${ }^{2}$ and Martina LABUDÍKOVÁ ${ }^{1}$
}

\title{
SCREENING OF THE SPATIAL DISTRIBUTION OF RISK METALS IN TOPSOIL FROM AN INDUSTRIAL COMPLEX
}

\author{
PRZESTRZENNY ROZKŁAD METALI NIEBEZPIECZNYCH \\ W POWIERZCHNIOWEJ WARSTWIE GLEBY \\ TERENÓW UPRZEMYSŁOWIONYCH
}

\begin{abstract}
For the sustainable development of urban areas, it is necessary to identify if environmental pollution exists and where hot spot pollution sources lie. In this study, 280 topsoil samples were collected from an industry estate in Zlin (the Czech Republic). In these samples, the presence of toxic metal was analyzed by energy dispersed X-Ray fluorescence (ED-XRF), and statistical analysis revealed that the major anthropogenic contaminants in the topsoil were $\mathrm{Pb}, \mathrm{Zn}$ and $\mathrm{Sn}$. Further contaminant analysis by atomic absorption spectrometry (AAS) determined the maximum contents of $28558.47 \mathrm{mg} / \mathrm{kg}$ for $\mathrm{Pb}, 1132.35 \mathrm{mg} / \mathrm{kg}$ for Sn and $2865.22 \mathrm{mg} / \mathrm{kg}$ for $\mathrm{Zn}$ in selected topsoil samples. According to soil pollution index results, the main proportion of topsoil is contaminated, with the possible sources of contamination being traffic and a nearby municipal heating plant. This study proves that the combination of preliminary ED-XRF topsoil analysis, a multivariative statistical approach, AAS analysis and the geographical information system (GIS) is effective and together form a powerful tool for mapping topsoil contamination and conducting an environmental risk assessment.
\end{abstract}

Keywords: industrial urban soil, pollution, heavy metals, multivariative statistics, cluster analysis, ED-XRF, AAS, GIS

\section{Introduction}

Soil has been perceived by human beings as a source of building materials and as the medium for farming, ergo the lowest component of the food chain. However, from an environmental point of view, soil should be perceived as an ecosystem, the quality of which is influenced positively or negatively by the mutual interaction of individual (animate and inanimate) components. For that reason, soil has to be considered an animate, dynamic and vitally important part of the ecosystem. Its quality should support the desirable development

\footnotetext{
${ }^{1}$ Department of Environment Protection Engineering, Faculty of Technology, Tomas Bata University in Zlin, nam. T.G. Masaryka 275, CZ-76272 Zlin, Czech Republic, phone: +420 576031411

${ }^{2}$ Centre of Polymer Systems, Department of Environment Protection Engineering, Faculty of Technology, Tomas Bata University in Zlin, nam. T.G. Masaryka 5555, CZ-76001 Zlin, Czech Republic

* Corresponding author: slavik@ft.utb.cz
} 
of plants and animals, as well as biological productivity, and should not be hazardous to human health [1-3].

According to the EU COM (2006) 232 directive proposal for soil protection, the member states of the EU have to identify localities where proven hazardous substances occur, as a consequence of human activities, in such quantities that represent a significant risk to human health or the environment. The risk must be quantified by taking present and future approved land use into consideration [3, 4]. Incidentally, a group of EU member states undertook the systematic monitoring of the quality of agricultural and forest soil in the past, which has been integrated into their legislation. However, the monitoring of urban soils has been neglected.

Even though the Czech Republic only joined the European Union in 2004, soil quality monitoring was actually carried out in 1990-1993. Most attention was paid to risk elements (As, $\mathrm{Cd}, \mathrm{Cr}, \mathrm{Ni}$ and $\mathrm{Pb}$ ) and persistent organic pollutants (PAH, PCDD/PCDF, DDT and styrene). It was found that only $2 \%$ of the total land mass of the Czech Republic $\left(78,865 \mathrm{~km}^{2}\right)$ was contaminated. The pollution was limited to small areas and tended not to indicate diffuse sources. The areas in the northern part of the Czech Republic (municipal heating and power plants, surface mining, the chemical industry), northern Moravia (heavy industry), and Prague and its environs (traffic emissions) as well as fluvial soil in the alluvium of large rivers (the Labe, the Morava) were very affected by both pollutant groups $[3,5]$.

Although the quality of agricultural and forest soil is monitored primarily for plant and tree farming on a large scale, attention has increasingly been focused worldwide on monitoring urban soil quality over the last three decades. Urban areas contain a great diversity of open spaces, including gardens, playing fields, wasteland, landfill sites, roads and railways, canal embankments and pockets of natural or seminatural land. The range of materials that comprise urban soil is much broader than that of rural or forested areas. However, the main problems associated with urban soil are contamination, compaction, poor drainage and stone content [1, 6-9].

Urban soil is regarded as the 'recipient' of a large quantity of diverse elements from many sources [10]. The physical (and chemical) environment of cities is profoundly affected by almost every kind of human activity, from deliberate acts of construction, management or vandalism to pollution, accidental or otherwise [1]. Due to continuous urbanization and industrialization in many parts of the world, various pollutants are emitted into the terrestrial environment and pose a great threat to human health $[11,12]$. Some organic pollutants can be biodegraded into less dangerous substances, however, the most serious problem concerns toxic inorganic metals because of their non-degradability, accumulation in the food chain, different mobility in soil and significant long-term effects on human health $[9,11,13,14]$.

The occurrence of risk (toxic) metals can be natural or anthropogenic. This naturally originates from the weathering of soil-forming rocks, whereas anthropogenic occurrence is diverse in character. Humans participate in activities producing a quantity and mix of emissions from different sources (power production, industrial and metallurgical production, traffic, etc.). From these, the main means of input into soil is via atmospheric deposition $[2,15,16]$.

Primarily, both monitoring soil input and measuring the content of risk elements must precisely determine the sources, whilst a secondary function is to assess the influence of 
these elements on the whole ecosystem. In the Czech Republic, Sanka [17] carried out a study to identify the sources of soil contamination and their impact on the health of the population of Brno. Soil and plant samples were analyzed for the presence of heavy metals $(\mathrm{Cd}, \mathrm{Cu}, \mathrm{Cr}, \mathrm{Ni}, \mathrm{Pb}$ and $\mathrm{Zn})$ and $\mathrm{PAH}$. The results displayed a significant difference between pollutant content in plants growing in an urban and suburban environment. Furthermore, it was discovered that the traffic in an urban environment is the major source of soil contamination by the elements of $\mathrm{Zn}, \mathrm{Cu}$ and $\mathrm{Pb}$. These conclusions corresponded with an earlier study of lead accumulation from petrol combustion on Californian roads, which was conducted between the years of 1976-1990. Due to the lead content of petrol being reduced from 0.4 to $0.15 \mathrm{~g} / \mathrm{dm}^{3}$ in 1986 , the atmospheric deposition of lead fell by approximately $50 \%$ and no doubt there was a reduction in the deposition of airborne lead into soil. However, it must be stressed that lead in soil is virtually immobile, that contamination is, in essence, a permanent phenomenon, and that the concentration of lead resulting from many years deposition will remain $[1,18]$. Conversely, in the case of $\mathrm{Zn}$, it has been found that this appears to be the most mobile of the studied elements; its mobility strongly depends on $\mathrm{pH}[19,20]$. Gong et al [9] have studied heavy metal contamination in urban and rural topsoil in Wuhan (China). They found that the contrasts between heavy metal contamination in soil and plants indicate that $\mathrm{Cd}$ is more easily absorbed by plants than $\mathrm{Zn}$ and $\mathrm{Pb}$. The same authors confirmed that atmospheric deposition is the main input of risk (toxic) elements into topsoil in studied areas. Similar results were obtained by Kremova et al [21], who monitored road-deposited sediment, soil and precipitation in Bratislava (Slovakia). Road-deposited sediment contained a higher concentration of $\mathrm{Cd}, \mathrm{Cu}$, $\mathrm{Fe}, \mathrm{Ni}, \mathrm{Zn}, \mathrm{Mn}$ and $\mathrm{Pb}$. The concentration of elements was highest in sediment, and because of that the sources of anthropogenic contamination were indicated as being traffic, industrial emissions and the burning of fossil fuels.

The process of quantifying the contamination is performed by analytical methods either described in specialist literature or given legislatively. The most significant difference in analytical methods resides in the devices used (laboratory or terrain), as well as in the demands of sample pretreatment (native sample analysis or mineralization). One of the most basic, cheap and relatively quick analysis methods is the measurement of magnetic susceptibility, as used, for example, by Hanesch and Schloger [22] in Austria. Their study compared the content of heavy metals in topsoil from two cities - Leoben and Vienna. The results revealed an important difference in the distribution of contamination; the contamination in Leoben was of the point form, whereas that in Vienna was of the areal form. Similarly, Sharma and Tripathi [23] used the measurement of magnetic susceptibility for monitoring topsoil contamination by heavy metals originating from fly-ash emissions in the surroundings of the point source. The authors affirm that the results of magnetic susceptibility measurement correlate well with the content of ferromagnetic minerals in topsoil, but for precisely determining contaminant content the other analytical method has to be used.

Today, the most widely used analytical methods for exactly determining inorganic elements are sample mineralization as observed by measurement on devices with Induction Coupled Plasma (ICP) or Atomic Absorption Spectroscopy (AAS). The differences between both methods have been described in detail by Duane et al [24]. They compared the results of heavy metal content in contaminated soil obtained on site via mobile ICP-MS and in a laboratory when off site by GF-AAS, ICP-AES and ED-XRF. The content of heavy metals 
was verified by standards from the European Community's Advanced Mobile Analytical Laboratory. The authors showed that, through the use of mobile ICP-MS and ED-XRF, accurate results were achieved, so too via the use of GAAS/ICP-AES. In the Czech Republic, it has been legislatively prescribed to utilize ICP-OES, ICP-MS, or ultimately AAS, to determine the content of risk elements in agricultural and forest soils [25]. Since 2007, the norm CSN EN 15309 has been put into practice for determining the elementary composition of waste and soil via E/WD-XRF methods. Garnebode [26] wrote that the presence of hazardous elements can be firstly determined by XRF and, on the basis of the preliminary results; the exact determination of hazardous elements can be carried out by AAS or ICP-OES. Nowadays, mobile XRF devices are available so it is possible to initially carry out topsoil contamination screening for inorganic elements, once the contaminated area has been localized, then after suitable soil sampling and mineralization, the exact content of hazardous elements via AAS or ICP can be determined. The benefit of that process is a substantial decrease in soil sampling and analysis costs.

At the present time, two methods are used for distinguishing between the origins of natural or anthropogenic contamination. The first involves the utilization of soil type standards with a known chemical composition, but their preparation is very difficult and the local properties of the soil studied are not always identical. Standards did not usually contain any determined analyte and they can be considered as environmental blank samples. The other way concerns (geo-)statistical methods during result analysis, where the mostly widely adopted methods are multivariative and cluster analysis [9, 27-32]. Since the beginning of this century the majority of studies [11, 21, 22, 27, 32-35] have used the combination of multivariative analysis and the visualization of research results by the geographical information system (GIS). An example is the work by Henshaw et al [33], who first presented the combination of statistical analysis and GIS visualization for geo-statistical and environmental based analyses. They visualized results using GIS from contamination found at a Superfund site in western Maryland. As a result of the development of GIS extensions, it is possible to find predictive models, too. Cheng et al [36] have used the combination of multivariative analysis and result visualization by GIS when mapping agricultural soil quality in Zhejiang province, China. For the soil's environmental quality, visualization was conducted via the model of Inverse Distance Weighted (IDW) interpolations, which is either part or an extension of various GIS software products. IDW is mostly used for creating continuous surfaces based on known values of point samples. The use of interpolating methods enables, with some probability, the prediction of contamination in places generally accessible and those that are not (under buildings, roads, etc.)

In its basic form, GIS is a database system with a distinguishing feature - one that deals with spatially (or geographically) referenced data. "Where" in addition to "what" is measured or observed is important, and is thus recorded and stored on the GIS database. These days, not only are maps created by GIS, but the functionality of GIS also extends to providing 3D, spatial and tracking analysis, as well as geo-processing and modeling. GIS is applied in numerous spheres, such as the military, medicine, environment protection, tourism and the protection of human health [33].

The aim of this pilot study is to identify major inorganic toxic metals which contribute to the heavy metal content in topsoil on an industrial estate. The employment of multivariate statistical techniques is used for determining the lithologic and anthropogenic origin of 
major inorganic pollutants, this in addition to visualizing their spatial distribution via GIS. The results of this study shall be the basis for topsoil monitoring over the long-term and the environmental risk assessment support system used for area sustainability.

\section{Methods}

\section{Site description}

Sampling the 280 topsoil samples was carried out on an industrial estate that once served the SVIT shoe production company. This is located near the centre of Zlin (the Czech Republic) in a part of the city lying at the bottom of a valley, through which the Drevnice river flows (Fig. 1). From a geo-morphological perspective, Zlin lies on a dissected region of the outer part of the western Carpathians, the uplands of Vizovice and the highlands around Hostyn and Vsetin. The terrain here is hilly and occasionally mountainous. This area is climatically classified as one with long warm and slightly dry summers, short and occasional mildly warm periods in the spring and autumn, whilst the winters are short and moderately warm and very dry with brief peaks in snowfall. The industrial estate and its surroundings are in area formed from Paleogenic rocks - Maguras flysch of the Racans tectonic unit, where lime clay alternates with glauconitic sandstone. In the fluvial plain of the River Drevnice, the bedrocks are covered with alluvial sediment up to a thickness of 3-4 m. Strata consists in the bottom part of coarse and largely earthy gravel of stones of about $20 \mathrm{~cm}$. The upper parts of strata consist of clay-like or silt/clay soil. The terrain's surface contains various types of anthropogenic backfill, as well as tiled and concreted areas [37].

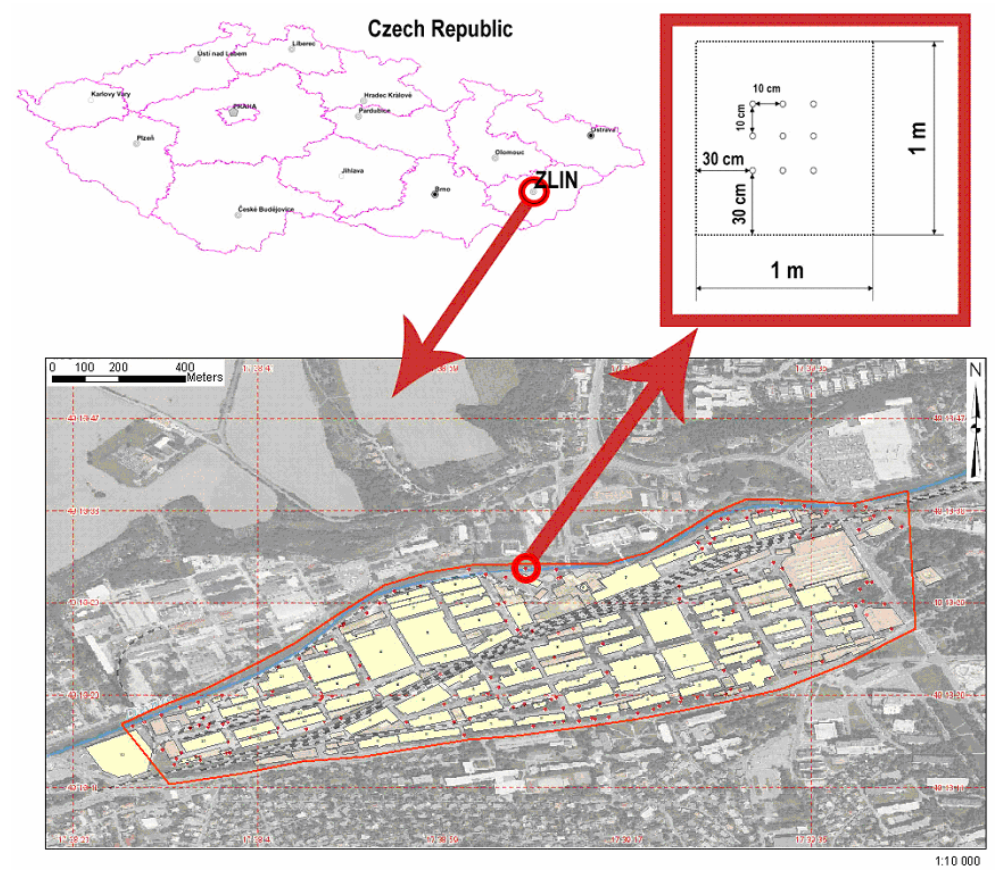

Fig. 1. Location and sampling map of the study area 
The bedrock forming the Paleogenic flysch rocks represents an environment with an almost fissure permeability in the area under study. Pore permeability is only evident in the uppermost weathered parts. The groundwater circle is retained within the fissure network and it varies depending on the abundance, shape and interactivity of fissures. Fluvial gravel of the alluvial plain represents a substantial and permeable collector of groundwater in the area. The direction of flow of groundwater generally matches that of the River Drevnice; at alluvial plain boundaries it is oriented towards the river. Groundwater refilling arises mostly through infiltration from the river, along with precipitation and surface run-off from the surrounding hillsides. The overlying stratum predominantly consists of clay soil, which has created a protective outer layer of gravel (ceiling insulator). In the area under study, the upper part of this layer is replaced or just filled in with loose dirt, permeable sections of ground and is disturbed by the presence of factory buildings [37].

From 1906, in Zlin, shoe production was centralized at the factory premises of the Bata shoe company. During a brief period of economic growth (ending in 1920), the Bata factory sites expanded. Following an engineering and power plant, other facilities were put up: a rubber factory, warehouses for raw materials and a garage. The factory even had its own airport in Otrokovice, dating from 1929. Eventually, the entire company site extended to cover approximately 92 ha. In 1948, all the premises were nationalized and renamed SVIT, and Zlin became known as Gottwaldov. After 1990, the SVIT factory went out of business and the city returned to the name Zlin. At the present time, various manufacturing and commercial activities are centralized in the former shoe production complex. Currently, there are plans to modernize and further develop the industrial estate, and it is for this reason that the environmental impacts of past industrial activities have to be assessed.

\section{Soil sampling}

The sampling points were all at accessible public places on the industrial estate. The points were located by a GPS device (Garmin GPSMAP 60 CSx Pro). No samples were taken at sampling points where access was hard to obtain. A square of $1 \times 1 \mathrm{~m}$ was measured out at each sampling point (see Fig. 1). Nine punctures were made with a hollow sampler at the depth of $0 \div 30 \mathrm{~cm}$ at each so dimensioned sample point. The $0.5 \mathrm{~kg}$ bulk samples were transferred into sealable polypropylene plastic sample boxes and transported to the laboratory for analysis.

At the sampling points, the intensity of the photonic dose equivalent was measured by the Gamma-Scout ${ }^{\circledR}$ device (Gamma-SCOUT GmbH \& Co. KG) in order to determine the impact of radioactivity on human health.

\section{Contamination analysis}

The screening analysis of inorganic contamination was carried out according to the European norm EN 15309:2007 for the characterization of waste and soil by XRF. In the laboratory, the samples were air-dried to a constant weight and ground to a maximum particle size of $150 \mu \mathrm{m}$ in a Retsch MM 301 vibratory ball mill, thereby homogenizing the samples. Firstly, the qualitative sample element composition was determined on an ED-XRF analyzer (Elvatech Ltd., Ukraine). According to the XRF's measurement results, multivariative and cluster analysis was accomplished and samples containing potential contaminants were selected for analysis via AAS. The exact quantity of contaminants was 
determined in accordance with the methodology prescribed by the Czech Ministry of the Environment - regulation MZP CR no. 13/1994 Sb., where one part of a sample is leached in a tenfold volume of $2 \mathrm{~mol} / \mathrm{dm}^{3} \mathrm{HNO}_{3}$ over 24 hours. The amount of contaminant in the leachate was determined by an AAS analyzer (GBC 933 AA).

\section{Data processing}

Raw data (GPS coordinates, the intensity of XRF spectral lines, contaminant amounts in the leachates and the intensity of the photonic dose equivalent) were stored on the MS Access ${ }^{\circledR}$ database. The statistical evaluation was conducted by the Statistica $6^{\circledR}$ program, which is able to carry out the multivariative, correlation and cluster analysis that can assess the relationships between the soil contaminants found and their origin.

Similarly to the work by Lee et al [11], the Soil Pollution Index (SPI) was calculated for each sampling point as follows: the sum of the fraction of the heavy metal concentration $\left(M C_{i}\right)$ in the sample, divided by the Czech regulatory level of the specific highly elevated heavy metal $\left(R L_{j}\right)$, was divided by the number of highly enriched heavy metals $(N)$ :

$$
S P I=\frac{\sum j \frac{M C_{i}}{R L_{j}}}{N}
$$

where: $i$ - sampling location number and $j$ - the number of highly enriched heavy metals.

Areal contaminant distribution and SPI were visualized by ArcGIS ver. 9.3.1 software, which contains the extension for Inverse Distance Weighted interpolation.

\section{Results and discussion}

\section{Pollutant identification}

The summary of elements found and determined by XRF analysis of 280 samples and the descriptive statistics are presented in Table 1.

Average values and standard deviation of spectral element intensity lines [cps] in soil samples

\begin{tabular}{|c|c|c|c|c|c|c|c|}
\hline Element & $\mathbf{C a}$ & $\mathbf{F e}$ & $\mathbf{S}$ & $\mathbf{S i}$ & $\mathbf{T i}$ & $\mathbf{S r}$ & $\mathbf{Z r}$ \\
\hline Mean & 4653.6 & 24336.8 & 126.9 & 3851.3 & 179.9 & 1985.0 & 1154.0 \\
\hline Maximum & 177280.0 & 195534.0 & 7914.0 & 29478.0 & 1105.0 & 10604.0 & 13488.0 \\
\hline SD & 18881.8 & 32760.5 & 909.0 & 4692.6 & 277.3 & 1932.8 & 2432.1 \\
\hline Element & $\mathbf{Z n}$ & $\mathbf{R b}$ & $\mathbf{P b}$ & $\mathbf{K}$ & $\mathbf{S b}$ & $\mathbf{S n}$ & \\
\hline Mean & 1783.0 & 834.8 & 2473.6 & 1015.3 & 8.6 & 473.9 & \\
\hline Maximum & 31731.0 & 3682.0 & 138494.0 & 10434.0 & 332.0 & 1633.0 & \\
\hline SD & 3896.1 & 923.8 & 15397.0 & 1460.4 & 47.7 & 548.9 & \\
\hline
\end{tabular}

Correlation coefficients were calculated for the elements and a correlation matrix created (Table 2). Good correlations between calcium and sulphur, potassium and silicium are highlighted in bold. Yalcin et al [31] reported that metals with a higher positive value of correlation coefficient in the matrix could originate from the same source. Benes [2] published that, in the Czech Republic, the main environmental pollutants are particles dispersed from energy power plants ( $\mathrm{As}, \mathrm{Be}, \mathrm{Cd}, \mathrm{Pb}, \mathrm{Hg}, \mathrm{Cu}, \mathrm{Zn}, \mathrm{F}$ and $\mathrm{V}$ ), the 
metallurgical and chemical industry ( $\mathrm{Fe}, \mathrm{Mn}, \mathrm{Cr}$ and $\mathrm{Ni}$ ), cement and lime works $(\mathrm{Ca}, \mathrm{Mg}$, $\mathrm{Cr}, \mathrm{Cu}, \mathrm{Pb}, \mathrm{Co}$ and $\mathrm{Ni}$ ), traffic emissions ( $\mathrm{Pb}, \mathrm{Cd}$ and $\mathrm{Sb}$ ), and facilities producing glass, enamel, bricks and fertilizer. With respect to the results obtained from XRF analysis, the possible source of risk elements in this soil can be fly-ash from the nearby municipal heating plant. This hypothesis is supported by other papers [2, 38-41], where is presented that, through incinerating wood, coal or waste, the initial trace elements $(\mathrm{Cd}, \mathrm{Cr}, \mathrm{Pb}, \mathrm{S}, \mathrm{Hg}$, $\mathrm{As}, \mathrm{Cu}, \mathrm{Ni}, \mathrm{Si}, \mathrm{K}, \mathrm{Ti}$ and $\mathrm{Ca}$ ) are concentrated in the burning products (ash and slag). As a consequence of these products' manipulation, contamination of the topsoil may occur.

Table 2

Coefficient correlation matrix between elements in soil samples (numbers in bold are significant at $\mathrm{p}<0.05, \mathrm{n}=280$ )

\begin{tabular}{|c|c|c|c|c|c|c|c|c|c|c|c|c|c|}
\hline & $\mathrm{Ca}$ & $\mathrm{Fe}$ & $\mathrm{S}$ & $\mathrm{Si}$ & $\mathrm{Ti}$ & $\mathrm{Sr}$ & $\mathrm{Zr}$ & $\mathrm{Zn}$ & $\mathrm{Rb}$ & $\mathrm{Pb}$ & $\mathrm{K}$ & $\mathrm{Sb}$ & $\mathrm{Sn}$ \\
\hline $\mathrm{Ca}$ & 1.00 & & & & & & & & & & & & \\
\hline $\mathrm{Fe}$ & 0.12 & 1.00 & & & & & & & & & & & \\
\hline $\mathrm{S}$ & $\mathbf{0 . 9 3}$ & 0.08 & 1.00 & & & & & & & & & & \\
\hline $\mathrm{Si}$ & 0.12 & 0.15 & -0.02 & 1.00 & & & & & & & & & \\
\hline $\mathrm{Ti}$ & -0.10 & 0.44 & -0.09 & 0.15 & 1.00 & & & & & & & & \\
\hline $\mathrm{Sr}$ & $\mathbf{0 . 5 0}$ & 0.38 & $\mathbf{0 . 4 9}$ & -0.05 & 0.32 & 1.00 & & & & & & & \\
\hline $\mathrm{Zr}$ & -0.09 & 0.13 & -0.07 & 0.07 & $\mathbf{0 . 6 6}$ & -0.06 & 1.00 & & & & & & \\
\hline $\mathrm{Zn}$ & 0.02 & 0.22 & -0.06 & -0.03 & 0.18 & 0.21 & -0.01 & 1.00 & & & & & \\
\hline $\mathrm{Rb}$ & -0.13 & 0.22 & -0.13 & 0.03 & $\mathbf{0 . 6 4}$ & 0.31 & 0.31 & 0.07 & 1.00 & & & & \\
\hline $\mathrm{Pb}$ & 0.03 & -0.05 & -0.02 & 0.45 & 0.01 & -0.09 & -0.01 & -0.02 & -0.05 & 1.00 & & & \\
\hline $\mathrm{K}$ & 0.03 & 0.13 & -0.10 & $\mathbf{0 . 9 7}$ & 0.14 & -0.07 & 0.07 & -0.05 & 0.04 & 0.37 & 1.00 & & \\
\hline $\mathrm{Sb}$ & -0.02 & -0.02 & -0.03 & 0.01 & -0.12 & -0.15 & -0.09 & -0.02 & -0.16 & -0.02 & 0.04 & 1.00 & \\
\hline $\mathrm{Sn}$ & 0.20 & 0.29 & 0.17 & 0.05 & 0.45 & $\mathbf{0 . 4 8}$ & 0.16 & 0.16 & $\mathbf{0 . 6 4}$ & -0.03 & -0.01 & -0.16 & 1.00 \\
\hline
\end{tabular}

The identification of potential contaminants was conducted via cluster analysis. Four groups of elements are present in the dendrogram obtained (Fig. 2). It is supposed that, with a higher dendrogram position (from $\mathrm{Sb}$ to $\mathrm{Ca}$ ), there is a decrease in the degree of anthropogenic origin and an increase in the degree of lithologic origin in topsoil. According to the geological map of the Czech Republic, the rocks belonging to the most recent geological era (Cenozoic middle Eocene - lower Oligocene) - glauconitic sandstone, calcareous claystone, sandstone, conglomerates and minor claystone exist in the study area. Therefore, it may be assumed that $\mathrm{Ca}, \mathrm{Mg}, \mathrm{Fe}, \mathrm{Si}, \mathrm{Al}, \mathrm{K}$ and $\mathrm{Na}$ are the main lithologic elements of uncontaminated topsoil.

However, in the dendrogram (Fig. 2), the first element group comprises $\mathrm{Ca}, \mathrm{S}$ and $\mathrm{Sr}$. The potential origin of $\mathrm{Ca}$ and $\mathrm{Sr}$ might be dolomitic limestone, which is utilized during desulphurization at the nearby heating plant. Indeed, desulphurization products are transported to the local landfill site, thus the elements ( $\mathrm{Ca}, \mathrm{Sr}$ and $\mathrm{S}$ ) can occur in topsoil.

The elements, from $\mathrm{Fe}$ to $\mathrm{Sn}$, form another wide group in the dendrogram (Fig. 2). Although $\mathrm{Fe}$ can be lithologic in origin in the topsoil of the studied area, anthropogenic sources, such as processing and storing steel materials, as well as corrosion from pipelines and the railway, have to be taken into consideration.

Finally, the most significant anthropogenic elements are $\mathrm{Pb}$ and $\mathrm{Sb}$, which are placed within the last group in the dendrogram (Fig. 2). Authors [2, 21, 42-44] have declared that the principal environmental sources of pollution of these elements are foundries and traffic. 


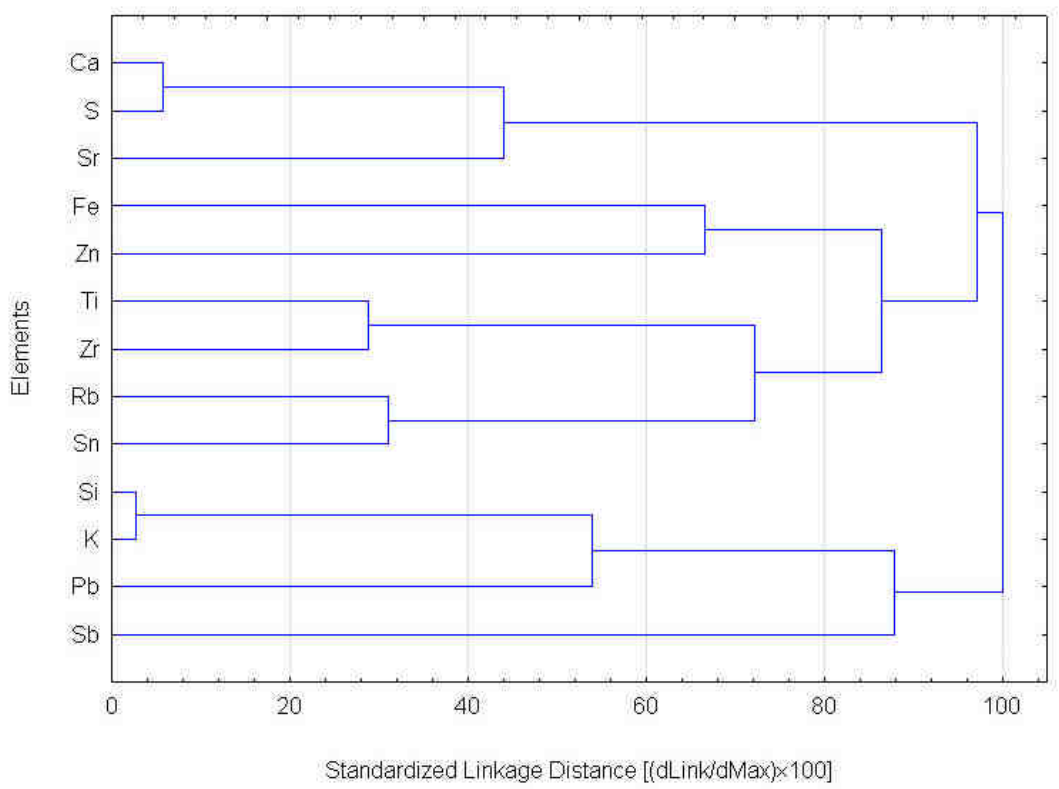

Fig. 2. Dendrogram of elements in soil samples based on ED-XRF spectral analysis

Taking into account the results of preliminary screening by XRF, the geological structure and mineralogical composition of rock in this particular environment, the foremost risk metals can be classified as $\mathrm{Pb}, \mathrm{Zn}, \mathrm{Sn}, \mathrm{Fe}$ and $\mathrm{Ca}$ in the topsoil samples. However, for a qualified decision on whether the enumerated metals represent such topsoil contamination, it is necessary to compare the metal content of samples with the valid legislated regulatory levels of the country.

\section{Spatial distribution of pollutants}

The comparison of potential risk metals with regulatory levels from the Czech Ministry of the Environment - methodical directive No. 8/1996 [45] - is presented in Table 3. The topsoil limit levels for $\mathrm{Pb}, \mathrm{Sn}$ and $\mathrm{Zn}$ were exceeded and, for that reason, attention shall now be focused on these metals. Benes [2] states that the lithologic origin of $\mathrm{Pb}$ should range between $7.0 \div 20.0 \mathrm{mg} / \mathrm{kg}$, with $\mathrm{Sn}$ in the range of $0.1 \div 6.0 \mathrm{mg} / \mathrm{kg}$ and $\mathrm{Zn}$ varying from $16.0 \div 95.0 \mathrm{mg} / \mathrm{kg}$ in main sedimentary rocks. If the values are compared with the medians of $\mathrm{Pb}, \mathrm{Zn}$ and $\mathrm{Sn}$ from Table 3, it can be seen that the medians are significantly higher. This may be the logical consequence of anthropogenic activity.

Czech regulatory levels and descriptive statistics of element content in soil samples and soil pollution index

\begin{tabular}{|c|c|c|c|c|c|c|}
\hline & Unit & Minimum & Maximum & Median & SD & RL \\
\hline $\mathrm{Pb}$ & {$[\mathrm{mg} / \mathrm{kg}]$} & 10.19 & 28558.47 & 38.56 & 2640.66 & 250 \\
\hline $\mathrm{Sn}$ & {$[\mathrm{mg} / \mathrm{kg}]$} & 1.19 & 1132.35 & 20.50 & 14.63 & 200 \\
\hline $\mathrm{Zn}$ & {$[\mathrm{mg} / \mathrm{kg}]$} & 16.73 & 2865.22 & 521.27 & 193.86 & 1500 \\
\hline $\mathrm{SPI}$ & - & 0.02 & 39.83 & 0.52 & 2.38 & $<1$ \\
\hline
\end{tabular}



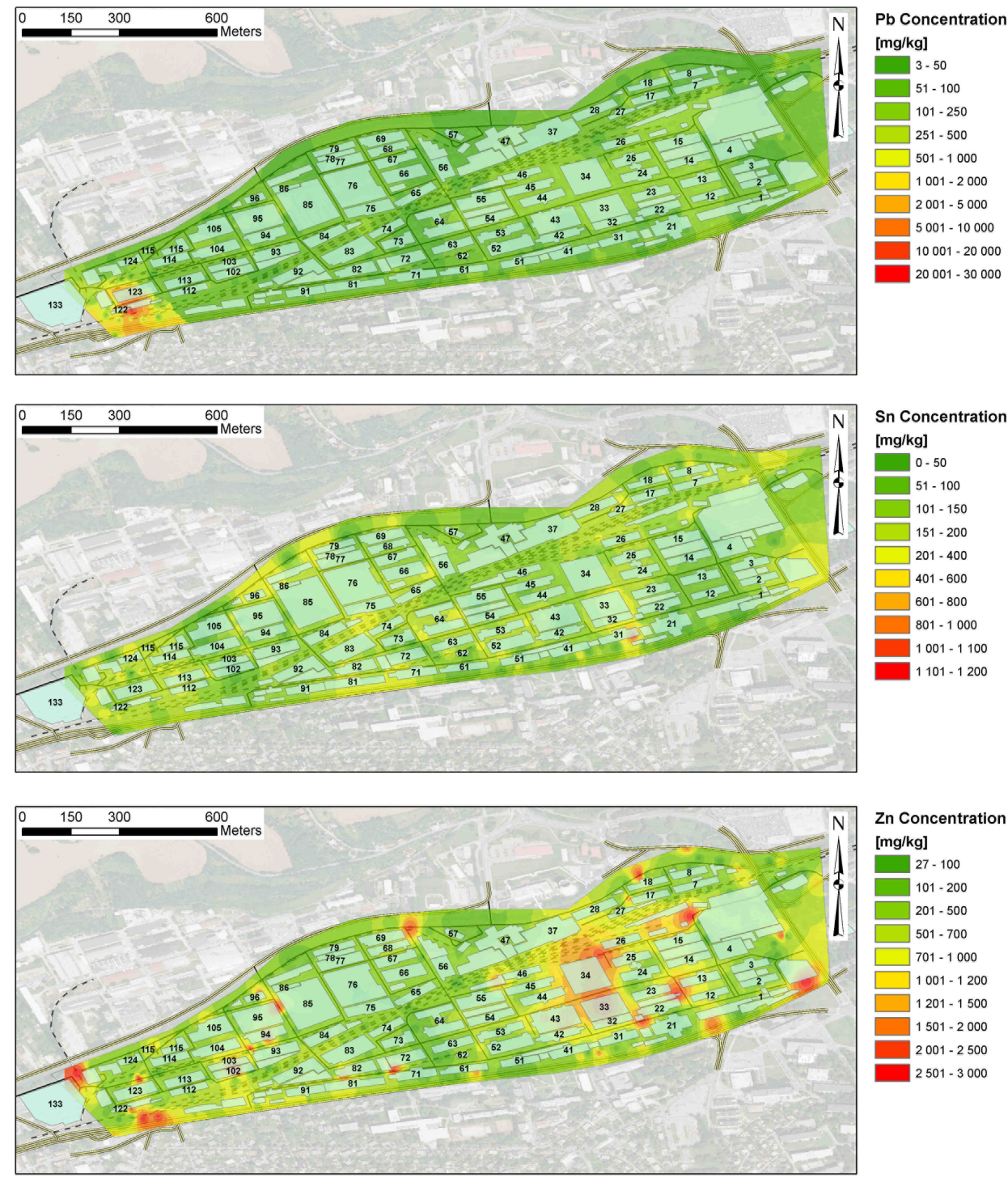

Fig. 3. Spatial distribution maps of $\mathrm{Pb}, \mathrm{Sn}$, and $\mathrm{Zn}$

The maps of metal spatial distribution have been generated by GIS. As can be seen from Figure 3, the spatial distribution of $\mathrm{Pb}, \mathrm{Sn}$ and $\mathrm{Zn}$ significantly differs. The highest topsoil content of $\mathrm{Pb}$ is concentrated in the southwest part between the road, railway and Building No. 122 (highest content $=28558.47 \mathrm{mg} / \mathrm{kg}$ ), where the value of the limit has been exceeded more than hundredfold. It is more than probable that here the remediation of lead has to be conducted. A likely source of contamination can be found near Building No. 122, where a car repair workshop and a scrapyard firm are placed. It is there that used lead 
batteries from cars, containing $\mathrm{PbO}_{2}$ and $\mathrm{PbSO}_{4}$, are replaced or repurchased. If the batteries are broken or damaged through manipulation, lead compound leakages can seep into the environment. In Figure 3 it can be seen that higher contents of $\mathrm{Pb}>250 \mathrm{mg} / \mathrm{kg}$ have been found in the eastern part of the industrial estate. Authors [2, 6, 8, 9, 46, 47] have stated that the occurrence of lead in topsoil relates additionally to industrial emissions, and to traffic. Until 1990, in the Czech Republic, lead tetraethyl was used as an antiknock additive in petrol. However, this compound is now banned and is not used; the lead topsoil content still remains high due products from past antiknock petroleum incineration.

Nevertheless, the greater content of $\mathrm{Sn}$ and $\mathrm{Zn}$ occurred unevenly, distributed throughout the entire area. However, identifying the source proves difficult in the case of Sn. Figure 3 shows that highest content of Sn $(1132.35 \mathrm{mg} / \mathrm{kg})$ was discovered in front of Building No. 31 (a hospital car park), with increased concentration alongside roads. The amount of Sn oscillates around the mid value of $521.27 \mathrm{mg} / \mathrm{kg}$ in the study area, so it can be supposed that a sizeable source exists there. For that reason, thought was paid to the local heating plant. At present, a mixture of black and brown coal is combusted in a fluidized bed; for gaseous combustion products, a desulphurization process is applied. Nevertheless, until 1995, the products of combustion were freely released into the air. Danihelka et al [48] have found through analyzing the type of Czech coal used for combustion in heating plants that the Sn content in coal ranges between $0.9 \div 2.4 \mathrm{mg} / \mathrm{kg}$. After combustion of the coal, and following product analysis, the content of Sn in particular emissions was $1 \div 85 \mathrm{mg} / \mathrm{kg}$, in fly-ash $2.5 \div 7.7 \mathrm{mg} / \mathrm{kg}$, and in bottom ash $1.6 \div 3.7 \mathrm{mg} / \mathrm{kg}$. Based on these results, it can be supposed that the $\mathrm{Sn}$ content in topsoil is probably residual, because the new technology now in place at the heating plant does not allow products of combustion to be dispersed in the air.

The last metal to be studied was $\mathrm{Zn}$, of which higher concentrations have been found primarily beside roads and railways. The maximum $\mathrm{Zn}$ content of $2865.22 \mathrm{mg} / \mathrm{kg}$ was determined near Building No. 122 (a car repair workshop), but a high amount - as much as $2000 \mathrm{mg} / \mathrm{kg}$ - was discovered by many other buildings, as can be seen in Figure 3. Near to buildings number 122 and 34, a railway track traverses the roads and could cause the higher $\mathrm{Zn}$ content in topsoil found there. This assumption confirms the geochemistry study of urban surface soil by Anderson et al [6], or Pratt and Lottermoser [47], who investigated the mobilization of traffic derived trace metals. It has been discerned that the $\mathrm{Zn}$ in the sediments alongside roads originates from tires, road signs and/or railings.

Another possible source of $\mathrm{Zn}$ can be shoe production, which took place at the SVIT industrial estate until 1990. A paper by Malik et al [12] focused on the study of soil contamination in the city of Sialkot (Pakistan) shows that a potential source of $\mathrm{Zn}$ was the zinc salts used for tanning. Another possible $\mathrm{Zn}$ source is rubber processing for tires and shoes, in which zinc oxide is used as an additive. Data from an archive revealed that plastic and rubber production for shoes was carried out in buildings numbered 43-46, 95 and 104 . In shoe production technology, chrome tanning and various rubber types were utilized. Due to this, the possible major sources of $\mathrm{Zn}$ might be the railway lines and traffic, in association with a minor $\mathrm{Zn}$ source of past shoe production.

In order to assess the level of total topsoil contamination, the soil pollution index (SPI) was calculated for each sampling point. The use of SPI is recommended by Czech legislation in localities where contamination can cause a threat to human health or the environment. Figure 4 show, that large parts of the studied area showed levels of $S P I>1$, 
which indicates a situation when remediation is necessary. In fact, within the estate, the western parts of Building No. 122, and in the eastern section, the environs of Building No. 34 must be decontaminated. Besides this, it is at Building No. 122 that the highest value of $S P I$ for the entire industrial estate was recorded, this being 39.83. As is stated in the paper by Carr et al [18], if the value of $S P I>5$, the topsoil is highly hazardous and presents a serious risk to human health. In such cases the situation requires remediation immediately. Under the circumstances, the origin of the metals is not lithologic but anthropogenic.
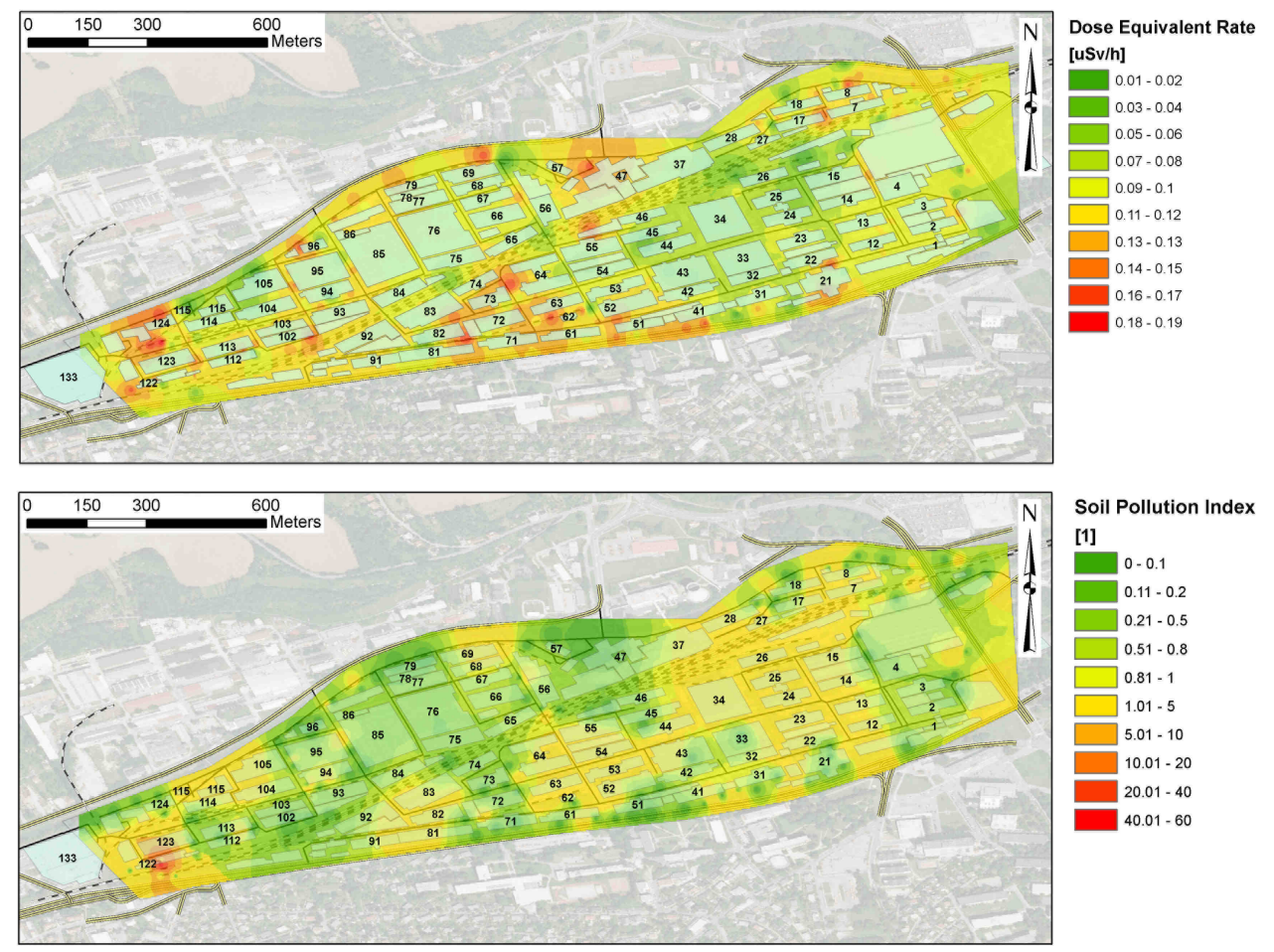

Soil Pollution Index [1]

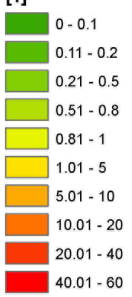

Fig. 4. Radiation Dose Equivalent Rate and Soil Pollution Index

In the area studied, the intensity of the photonic dose equivalent was measured and is visualized in Figure 4. However, the maximum value of $0.25 \mu \mathrm{Sv} / \mathrm{h}$, according to regulation No. 307/2002 Sb. of the Czech State Office for Nuclear Safety, has been not exceeded anywhere on the industrial complex. Therefore, it is not necessary to carry out any precautions to decrease exposure to radiation.

\section{Conclusions}

In the urban topsoil, a large amount of heavy metals, lithologic as well as anthropogenic in origin (traffic, industry, etc.), can be found. For that reason, knowledge of contaminated sites is necessary for their removal. The results of this work will be used as 
a basis for detailed and long-term monitoring of risk metals in the topsoil of the studied area.

The combination of multivariate statistical approaches, cluster analysis and GIS visualization seems to be very useful for interpreting soil environmental data sets. The use of multivariate analyses (CM and CA) by ED-XRF result processing helps to quickly identify the major anthropogenic elements $(\mathrm{Pb}, \mathrm{Sn}$ and $\mathrm{Zn})$ present in topsoil. In the selected samples, the exact content of risk elements was determined via the AAS method. It was found that in the western part of the industrial estate, the $\mathrm{Pb}$ content in topsoil reaches the extreme amount of $28558.47 \mathrm{mg} / \mathrm{kg}$, whilst, in the opposite eastern side, the content of $\mathrm{Zn}$ was $2865.22 \mathrm{mg} / \mathrm{kg}$ and that of $\mathrm{Sn}$ was $1132.35 \mathrm{mg} / \mathrm{kg}$, which indicates they were in excess of Czech regulatory limits. The visualization of spatial metal distribution and SPI was conducted by GIS. The maps created show that the distribution of contamination is not regular but depends on the kind of production process at specific sites. According to the SPI results, the places requiring immediate decontamination were identified, too.

\section{Acknowledgement}

This research was created with support of Operational Programme Research and Development for Innovations co-funded by the European Regional Development Fund (ERDF) and national budget of Czech Republic within the framework of the Centre of Polymer Systems project (reg. number: CZ.1.05/2.1.00/03.0111).

\section{References}

[1] Bullock P, Gregory PJ. Soils in the Urban Environment. London: Blackwell Scienctific Publications; 1991.

[2] Beneš S. Obsahy a bilance prvků ve sférách životního prostř̌edí. Část II. Praha: MŽP ČR; 1994.

[3] Kozák J, et al. Atlas půd České republiky. Praha: ČZU; 2009.

[4] EU: Proposal for a Directive $(\operatorname{COM}(2006) 232)$ of the European Parliment and of the Council establishing a framework for the protection of soil and amending Directive 2004/35/EC; 2006.

[5] Beneš B, et al. Životní prostředí České republiky. Vývoj a stav do konce roku 1989. Praha: Academia; 1990.

[6] Anderson M, Ottesen RT, Langedal M. Geoderma. 2010;156:112-118. DOI: 10.1016/ j.geoderma.2010.02.005.

[7] Davis HT, et al. Environ Pollut. 2009;157:2378-2385. DOI: 10.1016/j.envpol.2009.03.021.

[8] Szynkowska MI, et al. Pol J Environ Stud. 2009;18:1141-1150.

[9] Gong M, et al. Environ Geochem Health. 2010;32:59-72. DOI: 10.1007/s10653-009-9265-2.

[10] Li X, Feng L. J Hazard Mater. 2010;174:662-669. DOI: 10.1016/j.jhazmat.2009.09.102.

[11] Lee CS, et al. Sci Total Environ. 2006;356:45-61. DOI: 10.1016/j.scitotenv.2005.03.024.

[12] Malik R, Jadoon W, Husain S. Environ Geochem Health. 2010;32:179-191. DOI: 10.1007/s10653-0099274-1.

[13] Wang XS, Qin Y. Environ Geol. 2006;49:905-914. DOI: 10.1007/s00254-005-0122-z.

[14] Wang XS, Quin Y, Sang SX. Environ Geol. 2005;48:101-107. DOI: 10.1007/s00254-005-1270-x.

[15] Ljung K, Otabbong E, Selinus O. Environ Geochem Health. 2006;28:353-364. DOI: 10.1007/s10653-0059031-z.

[16] Manninen H, et al. Chemosphere. 1996;32:2457-2469. DOI: 10.1016/0045-6535(96)00146-4.

[17] Sanka M, et al. Int J Environ Anal Chem. 1995;59:327-43. DOI: 10.1080/03067319508041338.

[18] Carr R, et al. Environ Geochem Health. 2008;30:45-52. DOI: 10.1007/s10653-007-9106-0.

[19] Markiewiez-Patkowska J, Hursthouse A, Przybyla-Kij H. Environ Int. 2005;31:513-521. DOI: 10.1016/j.envint.2004.09.004.

[20] Franco-Uria A, et al. J Hazard Mater. 2009;165:1008-1015. DOI: 10.1016/j.jhazmat.2008.10.118.

[21] Krcmova K, et al. J Soils Sediments. 2009;9:304-316. DOI: 10.1007/s11368-009-0097-6.

[22] Hanesch M, Scholger R. Environ Geol. 2002;42:857-870. DOI: 10.1007/s00254-002-0604-1. 
[23] Sharma AP, Tripathi BD. Environ Monit Assess. 2008;138:31-39. DOI: 10.1007/s10661-007-9788-x.

[24] Duane MJ, Facchetti S, Pigozzi G. Sci Total Environ. 1996;177:195-214. DOI: 10.1016/00489697(95)04895-2.

[25] Regulation MZe No. 275/1998 Sb.: About agrochemical testing of farmland and determination of forest soil properties. Praha; 2004.

[26] Garnebode N. Nachr Chem. 2009;57:1118-1119.

[27] Chen T, et al. Environ Pollut. 2009;157:1003-1010. DOI: 10.1016/j.envpol.2008.10.011.

[28] Dragović S, Mihailović N. Environ Monit Assess. 2009;157:383-390. DOI: 10.1007/s10661-008-0543-8.

[29] Panichayapichet P, et al. Water, Air, Soil Pollut. 2008;194:259-273. DOI: 10.1007/s11270-008-9714-z.

[30] Tariq SR, et al. J Hazard Mater. 2005;122:17-22. DOI: 10.1016/j.jhazmat.2005.03.017.

[31] Yalcin MG, Narin I, Soylak M. Environ Geol. 2008;54:1155-1163. DOI: 10.1007/s00254-007-0884-6.

[32] Zhang CS. Environ Pollut. 2006;142:501-511. DOI: 10.1016/j.envpol.2005.10.028.

[33] Henshaw SL, et al. J Med Systems. 2004;28:335-348.

[34] Li XD, et al. Environ Pollut. 2004;129:113-124. DOI: 10.1016/j.envpol.2003.09.030.

[35] Skordas K, Kelepertsis A. Environ Geol. 2005;48:615-624. DOI: 10.1007/s00254-005-1319-x.

[36] Cheng J, Shi Z, Zhu Y. J Environ Sci. 2007;19:50-54. DOI: 10.1016/S1001-0742(07)60008-4.

[37] Janoška M. Valašsko očima geologa. Olomouc: Univerzita Palackého; 2000.

[38] Dahl O, et al. Fuel Process Technol. 2009;90:871-878. DOI: 10.1016/j.fuproc.2009.04.013.

[39] Singh H, Kolay PK. Water, Air, Soil Pollut. 2009;198:87-94. DOI: 10.1007/s11270-008-9828-3.

[40] Skodras G, et al. Fuel. 2009;88:1201-1209. DOI: 10.1016/j.fuel.2007.06.009.

[41] Chun-Gang Y. Microchim Acta. 2009;165:91-96. DOI: 10.1007/s00604-008-0103-5.

[42] Borgna L, et al. J Geochem Explor. 2009;101:137-146. DOI: 10.1016/j.gexplo.2008.05.001.

[43] Davies BE. Water, Air, Soil Pollut. 1997;94:85-98. DOI: 10.1023/A:1026478427782.

[44] Zehetner F, et al. Water, Air, Soil Pollut. 2009;198:125-132. DOI: 10.1007/s11270-008-9831-8.

[45] MŽP: Kritéria znečištění zemin a podzemní vody. Zpravodaj MŽP. Praha: MZP; 1996.

[46] Maher BA, Moore C, Matzka J. Atmos Environ. 2008;42:364-373. DOI: 10.1016/j.atmosenv.2007.09.013.

[47] Pratt C, Lottermoser BG. Environ Geol. 2007;52:437-448. DOI: 10.1007/s00254-006-0471-2.

[48] Danihelka P, et al. Int J Energy Res. 2003;27:1181-1203. DOI: 10.1002/er.942.

\title{
PRZESTRZENNY ROZKŁAD METALI NIEBEZPIECZNYCH W POWIERZCHNIOWEJ WARSTWIE GLEBY TERENÓW UPRZEMYSŁOWIONYCH
}

\begin{abstract}
Abstrakt: Dla zrównoważonego rozwoju obszarów miejskich istotna jest identyfikacja istniejących zanieczyszczeń środowiska i ich źródeł. Do badań pobrano 280 próbek wierzchnich warstw gleby z terenów zurbanizowanych miasta Zlin (Republika Czeska). W próbkach określono zawartość metali ciężkich metodą rentgenowskiej analizy fluorescencyjnej (ED-XRF). Na podstawie analizy statystycznej otrzymanych wyników stwierdzono, że główne zanieczyszczenia antropogenne w wierzchnich warstwach gleby to $\mathrm{Pb}, \mathrm{Zn}$ i Sn. Dalsza analiza zanieczyszczeń metodą absorpcyjnej spektrometrii atomowej (AAS) pozwoliła na określenie maksymalnych stężeń tych analitów w próbkach: $28558,47 \mathrm{mg} / \mathrm{kg}$ dla Pb, 1132,35 mg/kg dla Sn i $2865,22 \mathrm{mg} / \mathrm{kg}$ Zn. Na podstawie przeprowadzonych badań stwierdzono, że główne źródła zanieczyszczeń to ruch samochodowy oraz pobliska ciepłownia miejska. Przeprowadzone badania dowodzą, że połączenie wstępnej analizy gleb metodą ED-XRF, metod statystyki wielowymiarowej, analizy AAS i Systemu Informacji Geograficznej (GIS) jest skutecznym narzędziem oceny zanieczyszczenia wierzchniej warstwy gleby i oceny ryzyka dla środowiska.
\end{abstract}

Słowa kluczowe: przemysłowe gleby miejskie, zanieczyszczenie środowiska, metale ciężkie, statystyka wielowymiarowa, analiza skupień, ED-XRF, AAS, GIS 